\title{
Management of Character Education based on Islamic Academic Culture (Budai) for the Students of Universitas Islam Sultan Agung (Unissula) of Semarang
}

\author{
Khoirul Anwar' ${ }^{1}$, M.Muhtar Arifin Sholeh ${ }^{2}$ \\ FAI Universitas Islam Sultan Agung, Semarang ${ }^{1,2}$ \\ \{khoirul@unissula.ac.id ${ }^{1}$, muhtararifin@unissula.ac.id $\left.{ }^{2}\right\}$
}

\begin{abstract}
Character education in higher education requires serious improvement in its implementation management. So far, character education for students on campus has received less serious attention than character education in schools. Efforts to internalize and embody character values, especially religious character in students, need to be carried out continuously through a planned and integrated program. Character education must be sustainable and never stop as an integrated activity in preparing future generations with noble morals. One of the efforts that can be an alternative to improving student character education on campus is the development of character education management based on Islamic academic culture which is held integratively with various forms of religious activities on campus. Through the development of an academic culture based on Islamic values which became known as Islamic Academic Culture (BUDAI - Budaya Akademik Islami), students of the Universitas Islam Sultan Agung (UNISSULA) Semarang felt the atmosphere and climate of a religious campus as an effort to achieve the vision of "Bismillah Building a Generation of Khaira Ummah".
\end{abstract}

Keywords: Management, Character Education, Islamic Academic Culture (BUDAI - Budaya Akademik Islami)

\section{Introduction}

Until now, the Indonesian nation has been faced with complex problems related to the character of the nation. Various reports on juvenile crimes, including those involving students alternately adorn the mass media every day. This phenomena raises public questions about the role of education in shaping their character, which is generally as a student or university student. Whereas education should be an effort to prepare them to be able to live well in their communities, to be able to develop and improve their quality of life and to make a meaningful contribution in developing and improving the quality of life of the community and nation.

Departing from the apprehensive condition of the nation's character, character education has become a national issue that continues to be the government's attention to this day. Character education becomes a collective movement to create a friendly and moral education 
ecosystem. Various programs have been taken by the Government to promote character education, it's just that various criminal acts among adolescents are still ongoing. The various efforts in character education must be continued and need to receive support from all parties, both educational institutions, parents and the community. Especially character education among students who have so far received less attention, it is necessary to continue to look for ways to instill an effective character for them. Higher education is an educational unit that provides education service which is obliged to take part in shaping the character of the nation $[1]$.

Learning and teaching on campus is not only interpreted as an activity to transfer knowledge from lecturers to students. Various activities such as how to familiarize all academicians to carry out religious orders, be disciplined and obey the regulations that apply on campus, respect each other, get used to living clean and healthy and have a spirit of fair competition and the like are habits that must be cultivated in the campus environment, cultural bias-a good daily culture like this is commonly known as academic culture or campus culture.

Academic culture or campus culture is a key word that needs serious attention from higher education managers. It needs to be built based on the strength of the local cultural characteristics of the community where the campus is located. Campus culture is the heartbeat of the campus itself, its formulation must be done with a clear and measurable commitment by the campus community, namely lecturers, students, campus management, and the community. Through character education that is implemented in life on campus, it is hoped that students will have the character and noble character expected in educational goals.

The government, is currently incessantly implementing character education in educational institutions; starting from Elementary Schools (SD / MI), Junior High Schools (SMP / MTs), Senior High Schools (SMA / MA), to Higher Education. Through character education implemented in these educational institutions, it is hoped that the crisis of character or morality of the nation's children can be resolved. Various character education programs have been initiated by the government, to overcome the problem of the nation's character crisis. It's just that character education for students in tertiary institutions has not received the maximum attention as in the primary and secondary education levels. Departing from this background, this article will focus on the discussion of a character education management model for students based on Islamic Academic Culture at Universitas Islam Sultan Agung Semarang. Through its vision of "Bismillah Builds Generation of Khaira Ummah", the oldest Islamic College in Central Java is determined to build its students and alumni into the best generation who not only have scientific competence, but also have the best morals and character through its educational strategy known as "Islamic Academic Culture"(BUDAI).

\section{Research Method}

The research method in writing this article was to use qualitative methods. The qualitative approach was aimed at the background and individual being observed as a whole (holistically), so that the problem setting to be studied was in the form of institutions and individuals. The research was conducted at the Universitas Islam Sultan Agung (UNISSULA) Semarang. The research question in this article is how a character education management model based on Islamic Academic Culture at Universitas Islam Sultan Agung (UNISSULA) Semarang. Then how is the implementation in instilling a religious character for students of the Universitas Islam Sultan Agung (UNISSULA) Semarang. 
The research subjects were the head of the Institute for the Study and Application of Islamic Values (LKPI), lecturers and students participating in Islamic Religious Education (PAI) courses. The data were collected using interview, documentation and observation techniques. This research was carried out in a reasonable and scientific setting in a variety of concepts and theories developed based on conditions and realities in the field. To measure the validity of the data, data checking techniques commonly used in qualitative research were used. Meanwhile, data analysis is carried out in stages and are interrelated between data reduction, data presentation, drawing conclusions and verification.

\section{Results and Discussion}

\subsection{Management of Character Education}

Education is the main way of forming qualified, faithful and cautious human resources as well as competent and skilled. Education aims to shape the character of students as the nation's next generation. Education and character building are closely related and must be managed properly so that educational goals can be achieved. Character will shape human destiny and the welfare of a nation, therefore, character is very important and valuable for humans and the civilization of the people of a nation [2]. Character is the essence of nation and state because the loss of character will result in the loss of the identity of the nation's future generations.

Character education is positioned as the foundation for realizing the vision of national development, namely realizing a society with noble, moral, ethical, cultured and civilized characters based on Pancasila. Through character education, it is hoped that a transformation can occur that can foster and develop positive characters and change bad characters to be good for students. Thus, the character of students can be formed through moral modeling obtained in character education. In order for the implementation of character education to be carried out well, it is necessary to organize character education management at all levels of education.

Character education management is a management process that always pays attention to, considers and internalizes and integrates character values that come from the values of goodness, morals, culture, local wisdom, religious law, as well as the national order and government policies actualized in every management action. Education [3]. Character education management will be effective if it is integrated into campus management. In other words, character education on campus is closely related to management or management on campus, namely how character education is adequately planned, implemented, and controlled in educational activities on campus [4].

Integrating character education into lectures requires integrated planning. The implementation of character education along with its monitoring and evaluation must be well prepared. Character education is not sufficient in a direct way which has intellectual characteristics, because the values will only be absorbed or memorized but not internalized, let alone practiced [5].

Many opinions state that the goals of national education in general have not been fully achieved. This has resulted in the quality of graduates not being able to reflect the expected character desired by the goals of national education, because there are still many graduates who tend to be pragmatic, secular and materialistic. Namely intelligent intellectually and physically, but dry from the spiritual and lacks emotional and spiritual intelligence as expected [6]. That is, educational institutions, including tertiary institutions, should not only be obliged to increase academic achievement, but also be responsible for shaping the character of 
students, including students. It's just that because there are many demands that influence it, resulting in an emphasis on academic achievement that defeats the ideals of the role of educational institutions in character building.

Character education has become a problem in many countries, including Indonesia. Pros and cons emerge in the community who question its existence, where character education is an essential part of the task of educational institutions, but so far has not been given attention, especially among students. Lack of attention and the lack of proper character education learning concept has led to the development of various social diseases in society, such as rampant brawls between students, abuse of illegal drugs, promiscuity among adolescents and so on which are still a challenge in education World.

Resilience as a character of the Indonesian nation is very important in resisting all challenges and threats that can threaten the character of the nation. Because in today's information age, we cannot turn away or escape from this situation. Educators as educational agents are expected to be able to play an active role in efforts to improve the quality of Indonesian human resources who are intellectually intelligent, emotionally and spiritually intelligent. Therefore, educators and all components of education are required to always develop themselves because life is always changing and the value of a successful education is that there is a better change in students, both in knowledge and in character and morals.

If we want to develop a complete and comprehensive character education for students, actually the key is in campus culture. Because basically every university has a campus culture that is formed naturally through a network of interactions, relationships, communications and daily activities that become habits and routines. A morally friendly campus culture fosters professional responsibility and moral integrity of each member. The problem is that character education based on campus culture is not getting enough attention. In fact, what is often a concern, is class-based character education. Even discussions and talks about character education that often arise, for example whether or not new subjects are needed, such as moral education, character education, or character education; the definition of character education integrated in the curriculum; how to make a Characterized Teaching Program Plan (RPP) and implement it; as well as an evaluation system that is suitable for assessing the character development of students.

Society generally understands character education only in the context of the class. In fact, the learning process in the classroom, as well as how the passion for learning of students arises, often occurs because there are environmental factors that shape the culture and systems in campus organization and governance. The quality of character building for students on campus does not depend solely on the quality of making lesson plans (RPP) and other technical tools. More than that, character education is often very much dependent on its effectiveness from the quality of the culture that surrounds a university.

The development of a campus culture that respects moral values should be the main spirit of every university. Unfortunately, character education based on campus culture, although very important and has a major influence on the overall teaching and learning activities, has not received adequate discussion. In fact, since the government launched character education in 2010, character education based on campus culture has not been mentioned much. In government documents, the development of campus culture is only mentioned briefly by some examples through habituation, routine and exemplary activities [7]. Even in a document entitled Development of National Culture and Character Education, the focus is more on classroom learning, in the form of an active learning model. The government is very busy with the development of class-based character education which is narrow in nature, which is only in the teaching and learning process on campus, starting from designing lesson plans, teaching, 
to the learning evaluation process, and is busy defining the character building values that students need to master.

According to Koesoema [8], the discussion of character education based on campus culture is still very little. The government only says that character education based on campus culture is in practice integrated with extracurricular activities, such as Scouting or arts and cultural activities. Campus culture-based character education does not directly analyze and develop moral culture in the educational environment, but is busy dealing with activities that are carried out together in the form of habituation. Worse, character education based on campus culture is only understood as an activity that is carried out outside of classroom teaching activities, not as an integral part of the overall dynamics of praxis and interactions between individuals in an educational institution that forms a moral culture in the educational environment.

\subsection{Campus Culture}

The idea of character education for students based on campus culture which is understood as a fundamental part of developing character education has not been discussed too much. Various kinds of moral problems that arise in educational institutions show that our campus culture has not yet breathed the development of character education. In fact, culture is an atmosphere in which all the dynamics of education, both inside and outside the classroom, occur. Departing from this fact, this is where it is necessary to discuss the development of campus culture in relation to strengthening student character.

The government is indeed actively carrying out character education. However, according to Hidayat [9], without a good school / campus culture it will be difficult to carry out character education for students. If the school / campus culture is established, anyone who enters and joins the campus will almost automatically follow the school / campus culture. Thus, the campus culture or, more broadly, the culture of education, can be a strong foundation for the formation of student character. Culture is created, not inherited automatically. Therefore, understanding how a culture is formed, would be important, because if cultural renewal is to be carried out effectively, knowledge of how a culture is formed in individuals and then develops and inherits in a social norm, structure and system in society becomes an important guide. for us to design the development of a campus culture based on strengthening character for students effectively.

Higher education as an educational organization has a culture and characteristics that it embraces and is believed to be a guide for action. In campus culture, there are three main components, namely values, attitudes and evaluation. Campus culture is built by the work patterns that its residents do every day. This daily life forms a campus culture which is embraced as a value that has become a campus tradition. The tradition that is carried out by the academic community repeatedly becomes a ritual and then becomes a campus culture that its members will maintain from generation to generation and become pride.

Campus culture is dynamic, because basically campus culture reflects the way of thinking of the academic community in reforming. Campus culture is an embodiment of the vision and mission of all academicians in developing positive habits to shape the character of the campus. The expected character building is reflected in the campus culture that was created. Campus culture is reflected in: ritual activities, interactions in daily activities, curriculum development, extra-curricular activities, decision-making processes, setting competitive targets, building habits of cooperation, competing, and rewarding achievements which are continuously developed over and over again. 
The development of values in character education through campus culture includes all activities carried out by campus managers, lecturers, education staff, and students. Campus culture is an atmosphere of campus life where the academic community interacts with each other. The interactions that occur include between students and each other, campus leaders and lecturers, lecturers and lecturers, lecturers and students, education staff with students, lecturers, and others. These interactions are bound by various rules, norms, morals, and shared ethics that apply on a campus. Leadership, exemplary, friendliness, tolerance, hard work, discipline, social care, environmental care, a sense of nationality, responsibility, and a sense of belonging are some of the values developed in campus culture.

\subsection{Islamic Academic Culture (BUDAI - Budaya Akademik Islami)}

Universitas Islam Sultan Agung (UNISSULA) Semarang which has a vision of "Bismillah Building Khaira Ummah Generation" has developed and built a unique culture for its academics. His personality or culture is manifested in the form of mental attitudes, social norms, and behavior patterns of campus residents. A simple example of thinking about campus culture can be seen in the way they do things. This culture can influence all things that happen on campus, such as at the Universitas Islam Sultan Agung (UNISSULA) Semarang which has developed a campus culture with the name "Islamic Academic Culture" (BUDAI). This Islamic Academic Culture is an educational strategy at UNISSULA in order to achieve its vision. The culture that is built on this campus is based on Islamic values, which include, among other things, congregational prayer activities on campus, so that every academic community, starting from structural officials, lecturers, education staff and students from home has prepared themselves to be ready for congregation, even feel ashamed and strange if they do not follow the culture of the congregation on campus.

The academic community when they enter the campus area, will immediately adjust themselves. They will consciously and spontaneously follow the values, norms, ways and habits that apply on campus. When starting the lesson, the lecturers also began to carry out a series of activities that are usually carried out in the campus environment, such as praying, greeting and asking about the students, and so on. Initially, the campus culture at Universitas Islam Sultan Agung (UNISSULA) Semarang was formed in a formal network. A series of values, norms and rules are determined and determined by the campus as a guide for the campus academic community in thinking, behaving and acting. In its development, slowly the campus culture which later became known as the Islamic Academic Culture (BUDAI) will be embedded through informal cultural networks, because it has become a trade mark for educational institutions under the auspices of the Sultan Agung Waqf Foundation (YBWSA). Anyone who enters the campus area, they will and must adjust to the Islamic Academic Culture that applies on the campus.

Universitas Islam Sultan Agung (UNISSULA) Semarang strives to develop and build a unique culture that characterizes the institution and is constantly socialized and transmitted to its academic community. The Islamic Academic Culture, which is the hallmark of an institution, is able to encourage and motivate all its academics to achieve the goals desired by the campus. If the Islamic Academic Culture is emphasized or prioritized is strengthening student character, then all supporting activities such as learning activities and environmental strengthening will be directed towards achieving these goals.

The movement to realize the vision of "Bismillah Building Khaira Ummah Generation" at Universitas Islam Sultan Agung (UNISSULA) Semarang is used as the basis for developing a character education management model based on "Islamic Academic Culture". The 
development of a campus culture model at UNISSULA Semarang which became known as Islamic Academic Culture was focused on the application of Islamic values in the whole campus life in order to strengthen student character, especially religious character. Being religious is one of the character values in the form of being obedient to implementing the teachings of the religion that is followed. The existence of a religious campus culture known as Islamic Academic Culture (BUDAI) will develop the character achieved by the academic community, such as congregational culture, thaharah culture, Islamic dress and socialization culture, and other Islamic cultures.

Islamic Academic Culture as a cultural movement carried out at the Universitas Islam Sultan Agung (UNISSULA) Semarang is an effort to realize the vision of "Bismillah Builds the Khaira Ummah Generation" or (the best generation) which is projected to build a more noble character, namely character that comes from values. - Islamic values. Islamic Academic Culture needs to be developed in life on Islamic-based campuses. The development of the campus culture needs to be carried out continuously in order to support character education for students. Islamic Academic Culture as the development of campus culture at Universitas Islam Sultan Agung (UNISSULA) Semarang has been closely related to character education, especially in enhancing the religious character of students.

If students have a good religious character, this will directly affect their daily behavior and morals. The first step in applying character education on campus is to create a suitable campus atmosphere or climate that will help transform the academic community in the campus environment. All steps in this model of learning the values of religious character will contribute to character building for both students and other academicians. Character education is not only related to right-wrong problems, but how to instill habits about the good things in life, so that students have high awareness and understanding as well as concern and commitment to implementing good behavior in everyday life [10]. Given the need for a campus culture in the lives of students, the campus culture must be maintained and developed by treating Science and Technology as a process and product as well as a charity and moral paradigm. From an Islamic point of view, Islamic Academic Culture is a culture that places a philosophical and ethical foundation, namely the Al-Qur'an and hadith as the basis for all activities and teaching and learning processes for students.

Education is a culture, so Islamic Academic Culture is the culture of the application of Islamic values in the whole life on campus which is carried out by the academic community to achieve the vision, mission and goals of education on campus. The implementation is in the form of activities with Islamic values as the basis for the entire academic and non-academic process on campus which is carried out jointly and with full seriousness. Islamic Academic Culture also means culture which can be explained as an habituation of life with values that are believed to be true, because simply the essence of education is the cultivation or habituation of life with values that are believed to be true. Moreover, education on Islamic campuses such as at Universitas Islam Sultan Agung (UNISSULA) Semarang requires the application of Islamic values in the environment.

Universitas Islam Sultan Agung (UNISSULA) Semarang as a campus characterized by Islam is a campus that has formulated ideals (visions) which are abbreviated in the tagline "Bismillah Builds Khaira Ummah Generation ". This vision requires seriousness in realizing it, so it is necessary to build a joint and continuous movement by the entire academic community. As a strategy for achieving this vision, an Islamic Academic Culture (BUDAI) was established as an educational strategy to achieve that vision. Campus as a place to study, needs to instill Islamic values in students so that they are able to protect themselves from the negative cultural influences that are now spreading among the wider community. In 
accordance with the laws of the national education system regarding the goals of national education, namely to give birth to students who are faithful, devout, knowledgeable, and have good morals, are educational goals that are also in line with the goals of Islamic education. Meanwhile, the purpose of implementing Islamic School Culture itself is so that every student has the awareness to apply Islamic teachings in the campus environment, family and community.

In educational institutions of the Sultan Agung Waqf Foundation (YBWSA), including at Universitas Islam Sultan Agung (UNISSULA) Islamic Academic Cultural values generally cover two things, namely (1) strengthening science and technology (IPTEK) and (2) ) spiritual strengthening. In the end, both of these things are expected to create a climate in the campus environment to be full of Islamic values or by the term Islamic Learning Society (ILS). The Islamic Learning Society is a campus community that always upholds Islamic values, and makes Islam a view of life for the entire academic community, a source of inspiration, motivation, as well as a filter in scientific and cultural activities. Learning activities color the campus atmosphere, which makes the relationship between lecturers and students, between lecturers and lecturers, between students and students, always reflecting learning interactions based on Islamic values.

The philosophy that underlies it is that in fact man was created by Allah not without purpose. The presence of humans on earth has a number of mandates that are not just born, grow, reproduce and die, as befits the cycle of nature. Humans are created in the framework of the sincerity of Allah, as in the Koran which means: "Then do you think that we actually created you playfully (only), and that you will not be returned to Us?" (QS. 23: 115 This sincerity was shown by Allah by placing humans as Khalifah (QS.2: 30) and created in a perfect form (QS. At-Tin: 4). Humans were also created in groups and tribes as mentioned in QS. Al Hujarat : 13.

The best society (Khaira ummah) is a society whose members are elected individuals and pious individuals. Individuals who obey obey Allah's commands and stay away from what $\mathrm{He}$ prohibits. Such a society aspires to be the best society (Khaira Ummah) as the vision of the Universitas Islam Sultan Agung (UNISSULA) Semarang is based on the Al-Qur'an surah Ali Imran verse 110. Thus, "Building the Khaira Ummah Generation " becomes the theme principal of the education movement at Universitas Islam Sultan Agung (UNISSULA) Semarang. So the Khaira Ummah is the best people, the most superior people. So in the context of education, considering that the process is to prepare future history, the task of education is to prepare the best generations for a future which of course has the best character and character. The best generation is the one who wins the competition, who will lead the world. The task of education means a continuous process of giving birth to the best generation, preparing the best generation, preparing the khaira ummah generation. The generation for the best people who have the best character and character [11].

Meanwhile, the implementation of Islamic Academic Culture (BUDAI) at Universitas Islam Sultan Agung (UNISSULA) Semarang, which is supported by character education management, has succeeded in improving the religious character of students in the form of increased understanding and practice of Islamic teachings in their lives. This is because every day students are accustomed to the existing Islamic Academic Culture to always carry out Islamic teachings in their daily lives, such as congregational prayer, al-Quran tadarrus, Islamic dress, clean and healthy culture, disciplined culture and good morals. For this reason, all parties in the campus environment need to be involved in supporting the implementation of Islamic Academic Culture (BUDAI) as the basis for character education for students on campus. Given the factors that support the successful implementation of this campus culture 
development is the joint commitment of the entire academic community to realize the vision of the Islamic University of Sultan Agung (UNISSULA) Semarag "Bismillah Building Khaira Ummah Generation". The supports for Budai can be seen in the figure 1 below.

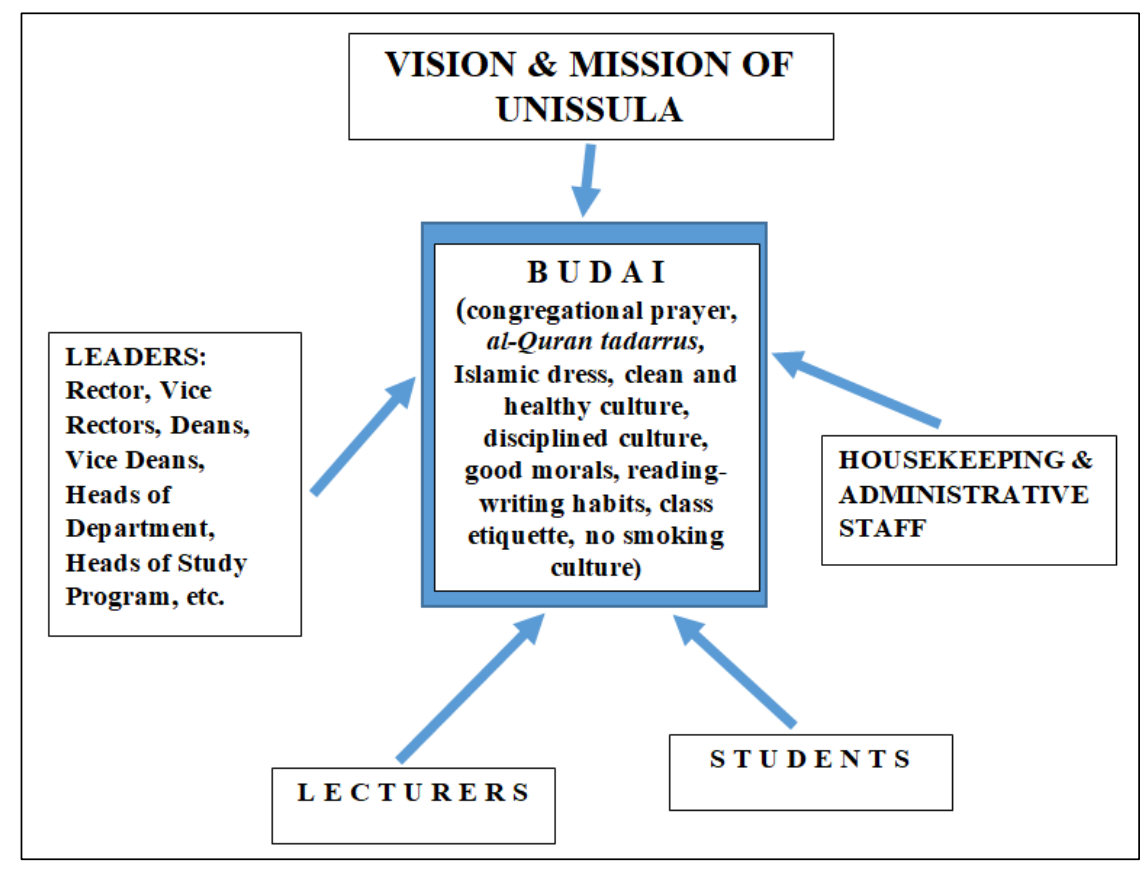

Fig. 1. Vision-Mission and Budai Supports

\section{Conclusion}

Cultivating character in the nation's children is not only the responsibility of schools, but also universities. For this reason, managers are required to fix the character education management which has received less attention so far. The management of character education for students must receive adequate attention as at the primary and secondary school levels. Character education in higher education must be carried out continuously and integrated with education management in each study program. Thus, the character education movement for students will become a joint movement in supporting the achievement of the vision that has been planned.

Universitas Islam Sultan Agung (UNISSULA) Semarang as an Islamic College in Central Java, has developed its campus culture into a campus culture based on Islamic values which has become known as Islamic Academic Culture (BUDAI). A conducive campus environment will support the formation of student character, for example, with an environment filled with Islamic values, students will have a more religious character. Islamic Academic Culture, which is an educational strategy at UNISSULA to achieve its vision of "Bismillah Builds the Khaira Ummah Generation ", is expected to be able to lead students and alumni to become the best generation, namely the generation that has noble character and morals. 


\section{References}

[1] Hasanah, H,: Implementasi Nilai-Nilai Karakter Inti di Perguruan Tinggi, Jurnal Pendidikan Karakter. Tahun III, nomor 2 Juni pp.187 (2013)

[2] Acetylena, Sita,: Pendidikan Karakter Ki Hadjar Dewantara. Malang: Madani. pp. 110 (2018)

[3] Arifin, Bambang Samsul,: Manajemen Pendidikan Karakter. Bandung: Pustaka Setia. pp. 21 (2019)

[4] Wibowo, Agus,: Manajemen Pendidikan Karakter di Sekolah. Yogyakarta: Pustaka Pelajar. pp. 137 (2016)

[5] Winarni, Sri,: Integrasi Pendidikan Karakter dalam Perkuliahan. Jurnal Pendidikan Karakter. Tahun III No.1 pp. 95 Pebruari 2013

[5] Zubaidi,: Strategi Taktis Pendidikan Karakter. Jakarta: Rajawali Pers. pp.4 (2017)

[7] Kementerian Pendidikan Nasional, Badan Penelitian dan Pengembangan, Pusat Kurikulum,: Pengembangan Pendidikan Budaya dan Karakter Bangsa Pedoman di Sekolah. Jakarta: Pusat Kurikulum (2011)

[8] Koesoema, Doni,: Pendidikan Karakter Berbasis Kultur Sekolah. Yogyakarta: Kanisius. pp.8 (2018)

[9] Hidayat, Komarudin,: KulturSekolah",http://www.uinjkt.ac.id/index/php/categorytable/1456.(2010)

[10] Mulyasa, HE,: Manajemen Pendidikan Karakter. Jakarta: Bumi Aksara. pp.8 (2014)

[11] Anwar, M Rofiq,: Risalah Bismillah Membangun Generasi Khaira Ummah. Semarang: YBWSA. pp. 37 (2011) 